\title{
Stabilising Earth Brick with Palm Kernel Oil Residue for Construction of Low Cost Housing
}

\author{
Yalley PP* and Badu E \\ University of Education, Ghana \\ *Corresponding author: Yalley PP, University of Education, Winneba, College of Technology Education, Kumasi, Ghana ;Email: ppyalley@gmail.com
}

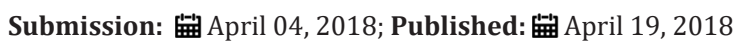

\begin{abstract}
The quest to explore alternative stabilising materials to fully or partially replace conventional stabilisers for improved engineering properties of earth bricks has resulted in an increased investigation into the potential use of agricultural and industrial waste as earth stabilisers. This study sought to determine the mechanical and durability properties of earth bricks stabilised with palm kernel oil residue (PKOR). The earth sample was prepared in accordance with BS 1881-127:1983 bricks stabilized with various percentages of PKOR were produced and tested for compressive strength, abrasion resistance and water absorption after 28-day curing age. The results showed that, earth bricks with $0 \%$ PKOR recorded the highest mean density (1822.00kg/m3 \pm 15.76388 ), while the density decreases with increased in PKOR content. Again, up to $4 \%$, addition of PKOR in earth bricks the compressive strength and Abrasion resistance progressively increased. The study concludes that, the addition of PKOR up to $4 \%$ by weight of earth significantly improved its mechanical and durability properties of earth bricks. The study recommends that for maximum strength and durability properties of earth bricks $4 \%$ of PKOR should be added to earth for brick production.
\end{abstract}

Keywords: Palm kernel oil residue; Earth bricks; Compressive strength; Abrasion resistance; Water absorption

Abbreviations: RHS: Rice Husk Ash; SDA: Saw Dust Ash; SCHA: Sugar Cane Husks Ash; CFA: Coconut Fibre Ash; PKSA: Palm Kernel Shell Ash; AHA: Acha Husk Ash; WA: Wood Ash; GHA: Groundnut Husk Ash; PKOR: Palm Kernel Oil Residue

\section{Introduction}

The construction industry is a vibrant sector of any economy since infrastructural development forms one of the indicators used in measuring a country's development [1]. The industry depends greatly on conventional materials such as cement, gravels and sand for the manufacturing of concrete and bricks. Cement undeniably is one of the most essential commodities in the construction sector. As a result of high cost and inaccessibility of cement the vast majority of people in developing countries where income levels are low and about half of the population lives in poverty, it will certainly be beyond the reach of many people to afford decent housing accommodation. In Ghana, the rising cost of building materials and its subsequent effects on construction in general has caused an increase in the housing deficit.

There has been an increased in research on the usage of alternative building materials, which are economically and environmentally friendly. Areas that have received adequate attention by researchers include agricultural materials as alternative chemical stabilisation of clays [2,3]. Some of the agricultural waste used are: rice husk ash(RHS), saw dust ash (SDA), sugar cane husks ash (SCHA), Coconut fibre ash (CFA), Palm kernel shell ash (PKSA), Corn cob ash(CCA), Acha husk ash (AHA), Bambara groundnut shell ash (BGSA), Bone powder ash (BPA), Groundnut husk ash (GHA), and Wood Ash (WA), periwinkle shell ash (PSA) [1-5].

Although, laterites used for producing bricks for masonry walls have been improved by the use of cement, bitumen or lime the quest for alternative cost effective replacement materials cannot be underrated due to the cost of the aforementioned stabilisers. Studies have over the years revealed that the chemical composition of lime is relatively similar to that of poultry egg shells. Thus, indicating the potential use of egg shell to improve the engineering properties of laterites [6-10].

The possible utilisation of palm kernel oil residue despite its availability, economic value and environmental friendliness has not yet been research into. It is on this basis that this study seeks to conduct an investigation into the engineering properties of palm kernel oil residue as earth brick stabiliser. Ghana has 305,758 hectares oil palm plantation and a production of 243,852 tons of palm oil with unmet demand of 35,000 tons. Palm kernel from which palm kernel oil and palm kernel oil residue (PKOR) are obtained, usually forms about 5 percent of the total weight of fresh fruit bunches. 
Various natural building materials (e.g. wood, straw, bamboo, soil) are used in developing countries for the building of what is often considered as sub-standard housing of a temporary nature.

The same view applies to low-cost urban housing built with a large variety of waste materials, such as scrap metal, cardboard, and so on. To produce materials of permanent nature, cement stabilised soil blocks should be of good-quality blocks, durable and as protective (against hot or cold weather, rain, wind, etc.) as building materials such as concrete blocks, fired bricks or building stones jointed with cement-based mortars. It is necessary, however, to choose carefully the raw materials for the manufacturing of stabilised soil blocks, to apply standard and appropriate soil preparation and to ensure that stabilised soil blocks produced are properly cured. The production of good-quality blocks also requires careful testing of the raw materials, especially soil, as well as testing of the output in order to ensure that blocks of the quality standard would be marketed. Therefore the main purpose of the study is to investigate into the physical, strength and durability properties of earth bricks stabilised with palm kernel oil residue (PKOR).

\section{Materials and Methods}

\section{Materials}

Natural earth, Palm kernel oil residue (PKOR) and Drinkable water were used.

\section{Sample preparation}

225 bricks of size $290 \times 140 \times 100 \mathrm{~mm}$ were stabilised with palm kernel oil residue with varied content from $0 \%$, to $8 \%$ with $2 \%$ incremental interval. The bricks were prepared in accordance with BS 1881-127:1983. The moisture content, dry density, plasticity index, linear shrinkage, organic content of the earth used were determined through standard test procedures and in accordance with BS 1377: 1992

A few small-sized bricks without PKOR as stabiliser were produced as a preliminary test to assess the optimum compression pressure that might be required to produce a brick of maximum strength. The optimum moisture content of soil in its natural state (not dried in oven) and also the mass of soil required to produce a batch of 15 bricks were also required. A BREPAK earth brick press (see Figure 1) that could deliver pressures of up to 35MPa for brick production was available in the laboratory.

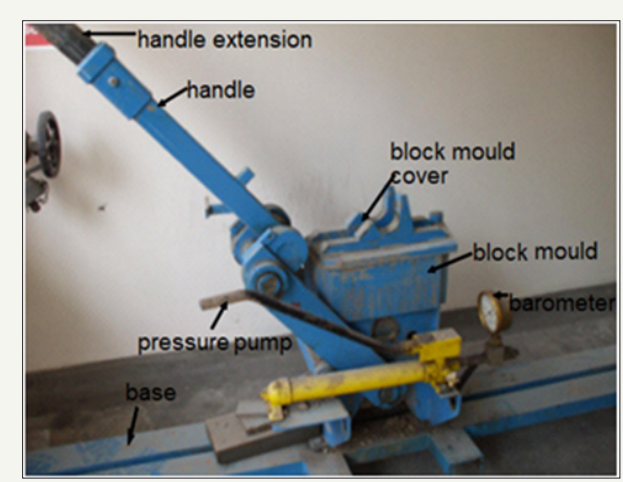

Figure 1: A BREPAK earth brick press.
Tests on dry density and moisture content of the earth in the natural state were first conducted on the earth bricks without stabilization to ascertain the optimum moisture content for the bricks production. Afterwards, chemical stabilisation was investigated by adding $2 \%, 4 \%, 6 \%$, and $8 \%$ of PKOR by weight of earth and its effect on the dry density, compressive strengths, abrasive and water absorption coefficients at different moistures contents were analysed after 28-days of air curing Figure $1 \& 2$.

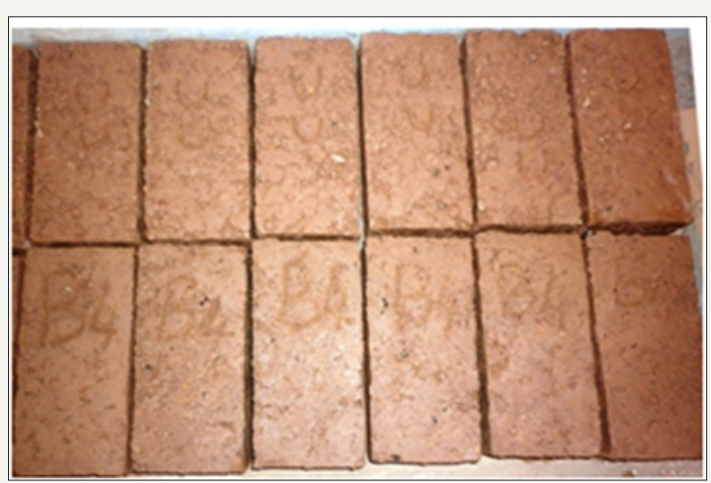

Figure 2: Freshly Moulded Earth Bricks.

Results

\section{Properties of soil used}

These preliminary experiments were conducted for several reasons. Firstly, the large number of independent variables could be reduced to a more manageable number. Secondly, relationships not covered in the literature could be identified. Thirdly, experimental values for those independent variables not held constant could be determined. Finally, experimental variability could be predicted and hence suitable sample sizes determined.

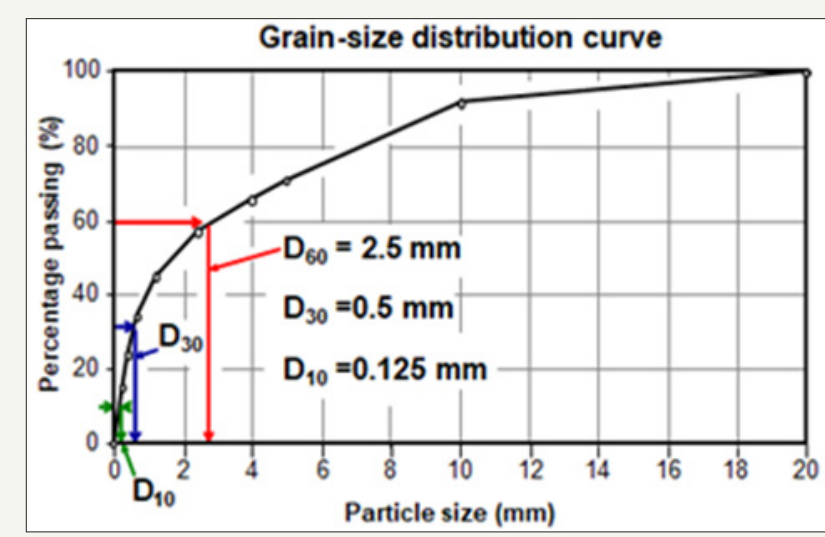

Figure 3: Particles size distribution gaps.

It could be seen from Figure 1 that the grading curve of the soil used was within the limit for well graded soil but with a small excess of $0.1 \mathrm{~mm}$ particles and small amount of fine particles. The soil had a coefficient of uniformity and gradation was 20 and 0.56 respectively. This soil is thus within the limit for well-graded intermediate clay content and gravel according to Head (1990) [4]. The ideal soil for soil blocks has a uniformity coefficient of 36 in which the particles fit together in the densest possible state of packing. The effective size $\mathrm{D}_{10}$ (the particle size where $10 \%$ of particles are finer) was found to be $0.125 \mathrm{~mm} . \mathrm{D}_{60}$ (the particle for 
which $60 \%$ of particles are finer) was found to be $2.5 \mathrm{~mm}$ Figure 3 . The various preliminary tests conducted were in accordance with (BS1377-2:1999: BS 5930:1999) from the results presented in Table 1 the earth material meet the requirement of earth block production.

Table 1: Properties of natural earth.

\begin{tabular}{|c|c|}
\hline Property & Result \\
\hline Colour & Reddish-brown \\
\hline Natural moisture content & $6.2 \%$ \\
\hline Organic matter content & $1.9 \%$ \\
\hline Specify gravity & 2.86 \\
\hline Free swell index & $42.9 \%$ \\
\hline Shrinkage limit & $12.20 \%$ \\
\hline Clay content & $11 \%$ \\
\hline Silt content & $15 \%$ \\
\hline Sand content & $68.35 \%$ \\
\hline Liquid limit & $38.7 \%$ \\
\hline Plastic limit & $27.3 \%$ \\
\hline Plasticity index & $11.4 \%$ \\
\hline Optimum moisture content & $12.3 \%$ \\
\hline Maximum dry density & $1950 \mathrm{Kg} / \mathrm{m}^{3}$ \\
\hline
\end{tabular}

The soil was found to have organic content of 1.9\% (Table 1). Houben \& Guillard as cited in Yalley \& Bentle [11], express the view that up to $2 \%$ of organic matter does not have a significant influence on the mechanical performance of the soil block. The soil used has a liquid limit of $38.7 \%$ plastic limit of 27.3 and plasticity index of $11.4 \%$ and hence the soil could be classified as moderately plastic clay according to plasticity chart of BS 5930:1999. It could be noticed that (Table 1) the soil used has a moderate clay content of $11 \%$ which is satisfactory for workability of the mixture and consolidation of the brick. The percentage of clay content in the soil satisfies the recommendation that suggests that an optimum fine content should be about $25 \%$, of which more than $10 \%$ should be clay (Gooding, 1993 as cited in [11]. The fine content in this case is $26 \%$, of which the clay content is $11 \%$.

\section{Compressive strength of earth bricks}

The addition of $4 \%$ PKOR improved the compressive strength of the bricks from $3.99 \mathrm{~N} / \mathrm{mm}^{2}$ to $4.29 \mathrm{~N} / \mathrm{mm}^{2}$. The compressive strength of bricks stabilized with PKOR increased as the PKOR increased. However, the compressive strength started decreasing beyond $4 \%$ addition of PKOR (Table 2). The minimum British Standard requirements of $2.8 \mathrm{~N} / \mathrm{mm}^{2}$ for masonry units as walling materials (BS 3921: (1985) and Ghana standard Board requirement of $1.9 \mathrm{~N} / \mathrm{mm}^{2}$. What this means is that, with suitable characteristics of local earth materials, the addition of PKOR in the right proportion by weight of earth, will improve the compressive strength of earth bricks, thereby making it fit for used as a masonry unit Table 2. The one-way ANOVA(F-test) with post-hoc showed evidence of significant difference $(F=19.194, d f=(4,20), p=0001)$ existing between the mean compressive strength of PKOR stabilised earth bricks and the unstabilised earth bricks at 1\% significance level $(\mathrm{p}<0.01)$. In terms of the PKOR's contribution to the variability in the dry compressive strength of the earth bricks, the study disclosed that, when other factors such as earth properties, method of production and compaction are controlled, about 72\% (adj. $\mathrm{R}^{2}=0.715$ ) of the strength variation in the earth bricks could be explained by the addition of PKOR [12-14].

Table 2: Compressive Strength of Palm Kernel Oil Residue Stabilised Earth Bricks Bricks.

\begin{tabular}{|c|c|c|}
\hline Specimens & M \pm SD $(\mathbf{M P a})$ & $\mathbf{F}(\mathbf{D F})$ P-value \\
\hline 0\% PKOR & $3.99 \pm 0.055^{\mathrm{a}}$ & $\mathrm{F}=19.194 ; \mathrm{DF}=(4,20)$ \\
\hline 2\% PKOR & $4.20 \pm 0.069^{\mathrm{ab}}$ & $\mathrm{P}=0.001$ \\
\hline $4 \%$ PKOR & $4.29 \pm 0.057^{\mathrm{ac}}$ & R Squared $=.760$ \\
\hline 6\% PKOR & $4.12 \pm 0.083^{\mathrm{ac}}$ & $\begin{array}{c}* \text { (Adjusted R } \\
\text { Squared }=.715)\end{array}$ \\
\hline 8\%PKOR & $4.03 \pm 0.036^{\mathrm{bc}}$ & \\
\hline
\end{tabular}

The one-way ANOVA(F-test) with post-hoc showed evidence of significant difference $(\mathrm{F}=19.194, \mathrm{df}=(4,20), \mathrm{p}=0001)$ existing between the mean compressive strength of PKOR stabilised earth bricks and the unstabilised earth bricks at $1 \%$ significance level $(\mathrm{p}<0.01)$

\section{Abrasive resistance}

The addition of PKOR to earth bricks as a stabiliser did improve the hardness of the earth bricks. The abrasion resistance increased as the PKOR content increased. However, the abrasion resistance started decreasing beyond $4 \%$ addition of PKOR similar trend to the compressive strength (Table 3).

The contribution of PKOR to the improvement of abrasion resistance property of earth bricks was found to be significant at 1 per cent level of probability $(F(4,20) 21.213$, p< 0.001$)$. The study revealed that only about $48 \%$ (Adj. $\mathrm{R}^{2}=0.475$ ) of the variability in the abrasion resistance of the earth bricks could be explained by the addition of PKOR. The remaining percentage $(52.1 \% \%)$ in variability as far as resistance to abrasion is concerned, could not be accounted for by the inclusion of the PKOR as a stabiliser. This implies that relying on PKOR alone for the improvement of the abrasion resistance of earth bricks is not enough (Table 3).

Table 3: Abrasion of palm kernel oil residue and unstabilised earth brick.

\begin{tabular}{|c|c|c|c|}
\hline Specimens & $\mathbf{M}\left(\mathbf{c m}^{2} \mathbf{~ g )}\right.$ & $\mathbf{S D}$ & $\mathbf{F}(\mathbf{D F}) \mathbf{P}$-value \\
\hline 0\%PKOR & 1.38 & 0.235 & $\mathrm{~F}(4,20)=21.213$ \\
\hline $2 \%$ PKOR & 3.62 & 0.714 & $\mathrm{P}=0.001$ \\
\hline $4 \%$ PKOR & 3.69 & 0.261 & \\
\hline 6\% PKOR & 3.52 & 0.579 & $\begin{array}{c}* \text { R Squared }= \\
.579\end{array}$ \\
\hline 8\%PKOR & 3.33 & 0.388 & $\begin{array}{c}\text { (Adjusted R } \\
\text { Squared }=.475)\end{array}$ \\
\hline
\end{tabular}

\section{Water absorption by capillary}

The results from Table 4 revealed that, the higher the content of PKOR in the earth brick, the lower the absorption of water. This could be due to the fact that the presence of PKOR eventually led 
to slower migration of moisture into the bricks. This decreasing ingress of water into the bricks with the corresponding increase in the PKOR content was anticipated because the stabiliser used PKOR is oil-based and as a result repels water. The oily films in the emulsion, coat the pore linings within the bricks after the water has evaporated from the brick upon curing and drying. This therefore has the tendency to repel and slow down the absorption rates of water into the bricks, and the more the PKOR content, the slower the absorption. The One- Way ANOVA (F-test) shown in Table 4 indicated that, PKOR as a stabiliser has significant effect on the water absorption property of earth bricks at a significant level of 1 per cent $(F(4,20) 25.094, p<0.001)$. This means that the addition of PKOR to earth bricks as a stabiliser did increased the resistance level of earth bricks as far as moisture penetration was concerned. The study revealed that about $86.0 \%\left(\mathrm{R}^{2}=0.86\right)$ of the variability in the abrasion resistance of the earth bricks could be explained by the addition of PKOR. This implies that PKOR as a stabiliser could be relied on as a suitable material to the improvement of the reduction in the rate of water absorption of earth bricks (Table 4).

Table 4: Water Absorption Rate of PKOR and Unstabilised Earth Bricks in.

\begin{tabular}{|c|c|c|}
\hline Specimens & M \pm SD (\%) & F(DF) P-value \\
\hline $0 \%$ PKOR & $1.22 \pm 0.072 \mathrm{a}$ & $\mathrm{F}=25.094 ; \mathrm{DF}=(4,20)$ \\
\hline $2 \%$ PKOR & $0.81 \pm 0.139 \mathrm{ab}$ & $\mathrm{P}=0.001$ \\
\hline $4 \%$ PKOR & $0.66 \pm 0.232 \mathrm{a}$ & $\begin{array}{c}\text { R Squared }= \\
.86(\text { Adjusted }\end{array}$ \\
\hline $6 \%$ PKOR & $0.58 \pm 0.099 \mathrm{a}$ & R Squared $=.74)$ \\
\hline $8 \%$ PKOR & $0.43 \pm 0.040 \mathrm{ab}$ & \\
\hline
\end{tabular}

\section{Conclusion}

The mean compressive strength obtained from the study when 4\% of PKOR was added, is about one and half times (4.29MPa \pm 0.057$)$ the minimum British Standard requirements of $2.8 \mathrm{~N} / \mathrm{mm}^{2}$ for masonry units as walling materials (BS 3921: ( 1985 ) and Ghana standard Board requirement of $1.9 \mathrm{~N} / \mathrm{mm}^{2}$. The implication of this is that when a structural work in the form of wall is to be constructed, PKOR could be used to stabilise the earth bricks in view of its ability to act as a binder to the particles of the earth. PKOR as a stabiliser could be relied on as a suitable material to the improvement of the reduction in the rate of water absorption of earth bricks. However, relying on PKOR alone for the improvement of the abrasion resistance of earth bricks is not enough.

\section{Recommendation}

From the results of the various tests conducted, it is has been established that PKOR has extremely enhanced the strength and durability properties of the earth brick. Consequently, PKOR stabilised earth bricks could be recommended for use in lowrise and low-cost housing projects in both dry and moderately damped environments with adequate render/plaster coatings. To manufacture low cost and environmentally friendly stabilised earth bricks for housing projects, it is worth examining alternative locally produced potential stabilising waste materials such as palm kernel oil residue (PKOR) which have lower energy requirement, low cost.

\section{References}

1. Atiemo E (2012) Improving Energy Efficiency in Construction and In the Production of Building Materials in Developing Countries. Kwame Nkrumah University of Science and Technology- Department of Civil Engineering, Ghana.

2. Amoanyi R (2012) Alternative chemical stabilization of clays with agricultural waste materials for rural housing. Kwame Nkrumah University of Science and Technology, Department of Civil Engineering, Ghana.

3. Yalley PP, Aseidu E (2013) Enhancing the Properties of Soil Bricks by Stabilizing with Corn Husk Ash. Civil and Environmental Research 2(11): 2224-5790.

4. Yalley PP (2012) Use of waste and low energy materials in construction.

5. Manu IY, Asiedu E, Yalley PP, Denutsui KS (2015) Feasibility of using Cocoa Pod Husk Ash (CPHA) as a stabilizer in the production of bricks, The International Journal Of Engineering And Science 3(6): 2091-2730.

6. Adogla F, Yalley PP, Arkoh M (2016) Improving Compressed Laterite Bricks using Powdered Eggshells Compressed Earth bricks, International Journal of Engineering Research and General Science Volume 3(6): 2091-2730.

7. King'ori AM (2011) A review of the uses of poultry eggshells and shell membranes. International Journal of Poultry Science 10(11): 908-912.

8. Gowsika D, Sarankokila S, Sargunan K (2014) Experimental investigation of eggshell powder as partial replacement with cement in concrete. International Journal of Engineering Trends and Technology14(2): 6568.

9. Karthick J, Jeyanthi R, Petchiyammal M (2014) Experimental Study on Usage of Eggshell as Partial Replacement for Sand in Concrete. International Journal of Advanced Research in Education Technology 1(1): 7-10.

10. Bashir ASM, Manusamy Y (2015) Characterization of raw eggshell powder as a good bio-filler. Journal of Engineering Research and Technology 2(1): 56-60.

11. Yalley PP, Bentle J (2009) Use of Baggase ash as soil stabiliser for soil bricks. Journal of Ghana Institution of Engineers, Issue 7(4): 2009.

12. British Standard Institution (1990) Methods of test for soils for civil engineering properties.

13. Kevern JT, Wang K (2010) Investigation of Corn Ash as a Supplementary Cementitious Material in Concrete.1370H Flarsheim Hall, University of Missouri-Kansas City, Kansas City, USA, p. 10.

14. Ghana Standard Authority (2010) Building and construction materialsspecification for blocks. 
(c) (i) Creative Commons Attribution 4.0 International License

For possible submissions Click Here
Advancements in Civil Engineering \& Technology

\section{Benefits of Publishing with us}

- High-level peer review and editorial services

- Freely accessible online immediately upon publication

- Authors retain the copyright to their work

- Licensing it under a Creative Commons license

- Visibility through different online platforms 